\title{
Comparison of Intramedullary and Extramedullary Fixation of Basicervical Fractures of the Femur in the Elderly: A Prospective Randomized Study
}

\author{
Yaşlanan Populasyonda Bazoservikal Femur Kırıklarında Intramedüller ve \\ Ekstramedüller Fiksasyonunun Karşılaştırılması: Prospektif Randomize Çalışma \\ ๑ Engin Eceviz, ๑ Hüseyin Bilgehan Çevik*, ๑ Güven Bulut \\ Kartal Dr. Lütfi Kırdar Training and Research Hospital, Clinic of Orthopedics and Traumatology, Istanbul, Turkey \\ ${ }^{*}$ Dışkapı Yıldırım Beyazıt Training and Research Hospital, Clinic of Orthopedics and Traumatology, Ankara, Turkey
}

Abstract

\begin{abstract}
Aim: Basicervical fractures of the femur are a unique type of unstable hip fracture, usually treated with sliding hip screw (SHS) or cephalomedullary nail (CMN). The aim of this randomized, prospective study was to evaluate the outcomes and complications of the two different treatment methods, SHS and $\mathrm{CMN}$, in the management of basicervical fractures of the femur in the elderly osteoporotic bones.
\end{abstract}

Methods: Patients aged over 65 years, who presented to our clinic with basicervical fracture of the femur between January 2016 and January 2018, were included in the study. The permuted block randomization method was used to randomize the participants into groups. The patients were allocated to one of two groups treated via CMN $(n=29)$ or SHS $(n=27)$. Functional and radiological evaluations included mobility score, Harris Hip score, modified Barthel index, Singh index, tip-apex distance, and fracture settling.

Results: Continuous improvement in the Barthel index was seen over the 12-month period in either group $(p<0.05)$. The average mobility score was found to be decreased at the $6^{\text {th }}$ week follow-up visits in either group $(p<0.05)$. The fracture settling measurements in SHS group was higher than in CMN group ( $p<0.01)$.

Conclusion: The clinical and radiological outcomes of both CMN and SHS groups showed no superiority of one technique over the other in the treatment of basicervical fractures of the femur.

Keywords: Basicervical, cervicobasiler, hip, fracture, prospective randomized
Öz

Amaç: Bazoservikal femur kırıkları genellikle kayan kalça vidası (KKV) veya sefalomedüller çivi (SMç) ile tedavi edilen dengesiz bir kalça kırığı tipidir. Bu randomize prospektif çalışmanın amacı, yaşlı osteoporotik kemiklerdeki bazoservikal femur kırıklarının tedavisinde kullanılabilen iki farklı tespit yöntemi KKV ve SMÇ'nin sonuçlarını ve komplikasyonlarını değerlendirmektir.

Yöntemler: Bu prospektif, randomize çalışmaya Ocak 2016'dan Ocak 2018'e kadar bazoservikal femur kırığı olan 65 yaş üstü hastalar dahil edildi. Katılımcılar blok randomizasyon yöntemi ile gruplara ayrıldı. Hastalar SMç $(n=28)$ veya KKV $(n=28)$ ile tedavi edilen iki gruba ayrıldı. Fonksiyonel ve radyolojik değerlendirmelere mobilite skoru, Harris Kalça skoru, modifiye Barthel indeksi, Singh indeksi, tip-apeks mesafesi ve kırık hattında çökme mesafesi dahil edildi.

Bulgular: Her iki grupta da Barthel indeksinde 12 aylık dönemde sürekli iyileşme görülmüştür $(p<0,05)$. Ortalama mobilite skorunun, her iki grupta 6 . hafta kontrolünde azaldığı görüldü $(p<0,05)$. KKV uygulanan bazoservikal kırıklarda kırık hattındaki çökme mesafesinin SMÇ uygulanan gruptan daha yüksek olduğu görüldü $(p<0,01)$.

Sonuç: SMÇ ve KKV uygulanan grupların klinik ve radyolojik sonuçları, bazoservikal femur kırıkları tedavisinde bir implantın diğerine üstünlüğü olmadığını açıkça göstermiştir.

Anahtar Sözcükler: Bazoservikal, servikobaziler, kalça, kırık, prospektif randomize
Address for Correspondence/Yazışma Adresi: Hüseyin Bilgehan Çevik, Dışkapı Yıldııım Beyazıt Training and Research Hospital, Clinic of Orthopedics and Traumatology, Ankara, Turkey Phone: +90 31259620 00/2253 E-mail: bilgehancevik@gmail.com ORCID: orcid.org/0000-0003-1945-3715 Received/Geliş Tarihi: 27 October 2019 Accepted/Kabul Tarihi: 30 January 2020
${ }^{6}$ Copyright 2020 by The Medical Bulletin of istanbul Haseki Training and Research Hospital The Medical Bulletin of Haseki published by Galenos Yayinevi.

${ }^{\circledR}$ Telif Hakkı 2020 istanbul Haseki Eğitim ve Araştırma Hastanesi Haseki Tıp Bülteni, Galenos Yayınevi tarafından yayınlanmışıtır. 


\section{Introduction}

Anatomically, basicervical fractures of the femur are intracapsular (1) but biomechanically, they are classified as extracapsular (2). Therefore, these fractures have been considered to be in the borderline category. However, clinically and biomechanically, these fractures behave like intertrochanteric hip fractures, which are usually treated with sliding hip screw (SHS) or cephalomedullary nail (CMN) instead of hemiarthroplasty (2-5).

Some studies have reported better results with the use of SHS in intertrochanteric fracture treatment and others have stated that CMN give better results (6-8). However, the current approach to the treatment of unstable intertrochanteric fractures is the use of CMN (9-11). It has been reported that basicervical fractures could also be evaluated as unstable fractures (12).

There are very little data in the literature regarding the comparison of clinical outcomes of CMN and SHS used in basicervical fractures of the femur (10). There have been several studies of the biomechanical properties of CMN and SHS, which have not shown any clear superiority of either implant in the treatment of these fractures $(4,9,13)$. The objective of this randomized, prospective study was to evaluate the rate of basicervical fractures of the femur and to compare outcomes and complications of the two different treatment methods of SHS and CMN.

\section{Methods}

\section{Study Design}

Approval for the study was granted by the Local Ethics Review Board of Dr. Lütfi Kırdar Training and Research Hospital and all the procedures were performed in accordance with the principles of the Declaration of Helsinki (1964). The study was registered at ClinicalTrials. gov (NCT04240743). Patients with a basicervical femur fracture were identified on admission to the emergency department of our tertiary hospital from January 2016 to January 2018. Patients, who were scheduled for surgery, met the inclusion criteria and provided written informed consent, were included in the study.

The patients were randomly allocated to a study group by permuted blocks of randomly mixed sizes and stratification according to the type of surgery (CMN or SHS). Randomization was applied using pre-prepared randomization cards, which were placed in opaque, sealed envelopes and given to the surgeons to open just prior to surgery, and the designated procedure was then performed.

\section{Preoperative Assessment}

Eligible patients were prospectively enrolled over a two-year period. The inclusion criteria were a basicervical fracture, age $\geq 65$ year, an isolated fracture, ability to walk independently (with or without an aid) before fracture, and a fracture that had occurred less than one week prior to admission. The exclusion criteria were a history of ipsilateral femoral fracture, a fracture due to malignancy, limited life expectancy due to medical comorbidities, any contraindication to surgery, diagnosed dementia, or any other traumatic fracture on admission.

\section{Surgical Procedure}

Closed reduction of the fracture was performed under fluoroscopic guidance on a traction table. Then the relevant surgical procedure was applied for implantation of CMN or SHS. Two senior surgeons (E.E, G.B.) with more than 10 years of surgical experience in treating basicervical fractures of the femur were familiar with both surgical techniques.

\section{Cephalomedullary Nail Technique}

For patients in the CMN group (Figure 1), an incision was made in the gluteal area from the tip of the greater trochanter in proximal orientation. A guidewire was placed into the medullary canal from slightly medial to the exact tip of the greater trochanter. The entry point of the greater trochanter and proximal medullary canal were reamed. The CMN was then inserted and fixed to the femoral head with a two lag screws. The nail was then locked distally using a guide arm. These CMNs were not locked proximally to maintain dynamization and to allow compression across the basicervical fracture line. In this
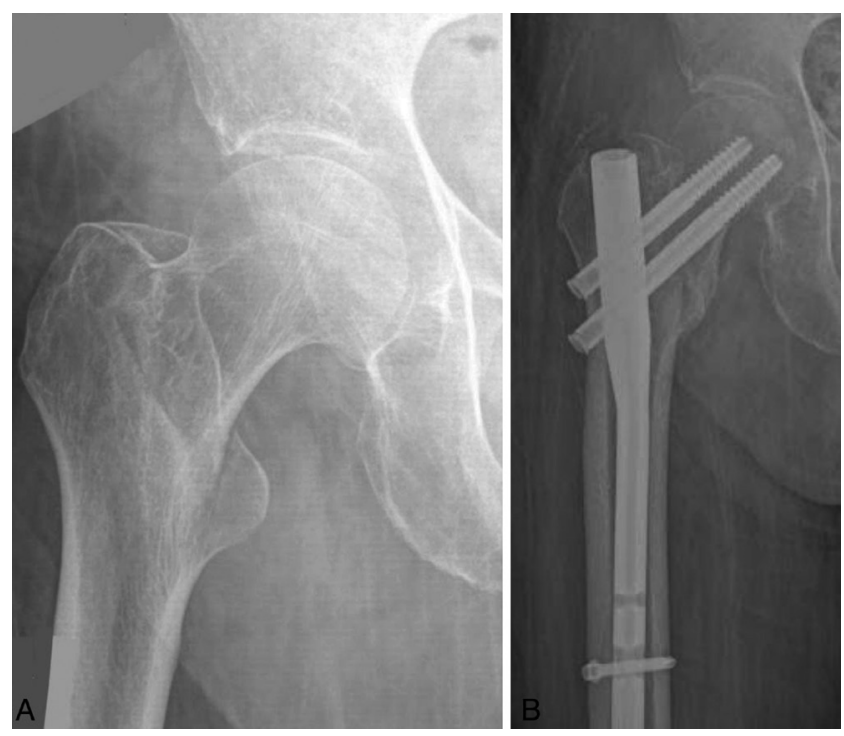

Figure 1. Anteroposterior X-ray view of a 72-year-old female patient showing a basicervical femur fracture of the right hip (A). A postoperative $6^{\text {th }}$ month anteroposterior X-ray view of the same patient undergoing insertion of CMN fixation of an osteoporotic basicervical femoral fracture of the right hip (B) 
study, all patients were treated with short nails (Profin ${ }^{\circledR}$ TST).

\section{Sliding Hip Screw Technique}

For patients in the SHS group (Figure 2), a lateral incision was made over the lateral proximal aspect of the femur. Under fluoroscopic guidance, the lag screw was placed centrally in the femoral head over the guidewire. A side plate with three holes was then attached to the hip screw (DHS plate, TST).

\section{Postoperative Follow-up}

Postoperatively, all patients were allowed immediate weight-bearing as tolerated, regardless of the method of fixation. All patients were followed up clinically and radiologically for a period of 12 months. The clinical and radiological evaluations were performed immediately postoperatively, then at 6 weeks, 3, 6 and 12 months.

Functional outcomes were evaluated with a Mobility score (range: 0-9) (14), and the Harris Hip score (15). Functional independence in daily living (10 basic activities of daily living) was evaluated with the modified Barthel index (range: 0-100) (16). The clinical follow-up evaluations were performed by two independent orthopaedic surgeons who had access to all the patients' files and documents. They were also blinded to the preceded treatment.

The singh index was used to grade preoperative osteoporosis in the contralateral proximal femur from anteroposterior $(\mathrm{AP})$ radiographs $(17,18)$. AP and lateral radiographs were evaluated for any change in implant position, using the tip-apex distance, and fracture settling $(19,20)$. The quality of reduction was evaluated on the postoperative radiographs, and graded as good $\left(<10^{\circ}\right.$ varus/valgus and/or ante- or retroversion), acceptable (5-
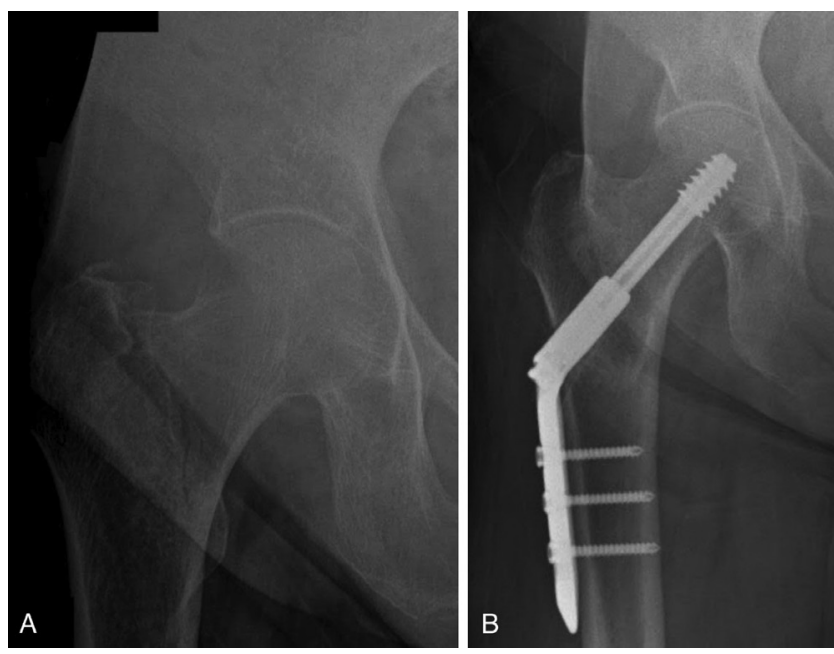

Figure 2. Anteroposterior X-ray view of a 66-year-old female patient showing a basicervical femur fracture of the right hip (A). A postoperative $6^{\text {th }}$ month anteroposterior X-ray view of the same patient undergoing insertion of a SHS (B) $10^{\circ}$ varus/valgus and/or ante- or retroversion), or poor $\left(>10^{\circ}\right.$ varus/valgus and/or ante-or retro- version) (21). The radiographic evaluation was performed by two different independent orthopaedic surgeons.

\section{Data Management}

The convenient clinical and radiological data were collected. The data were entered into a Microsoft Office Excel sheet. All participants in the study were assigned a four-digit number and the radiographs were placed in digital folders. No personal data on the individual patients was transmitted.

\section{Statistical Analysis}

The statistical analysis was performed using the SPSS for Windows (SPSS Inc, Chicago, Illinois). Odds ratios and means were compared between the groups, with 95\% confidence intervals and a $p$ value of less than 0.05 was considered statistically significant.

In order to calculate the sample size, a comparison of proportions method was used. A total sample size of 100 patients was calculated to show a difference on the order of $25 \%$ between the treatment groups at 12 months follow-up, with $80 \%$ power and $5 \%$ significance level. Twenty-five percent was the predicted difference in functional and radiological outcomes between the two fixation methods, and based on the previous unit data, an attrition rate of $10 \%$ was assumed.

\section{Results}

A total of 64 patients, who met the inclusion and exclusion criteria, and were willing to participate, were included in the study. The flow diagram of the study according to the Consolidated Standards of Reporting Trials 2010 is presented in Figure 3 (22). Registration in the study was terminated when the planned sample size was reached. Of the 64 patients, 32 were treated with SHS and 32 with CMN. Eight patients, who did not attend the 12-month follow-up examination, were excluded as clinical information was not available. The reasons for loss to follow-up were mortality in six (unrelated to hip surgery) and non-attendance at the final follow-up in two. Thus, final evaluation was made of 56 patients. Implant removal/revision surgery was not required in any patient during the study period.

The total 56 patients comprised 13 male and 14 female patients in the SHS group, and 15 male and 14 female patients in the CMN group, with a mean overall age of $80.75 \pm 7.54$ years. The detailed distributions of preoperative features are given in Table 1.

The average tip-apex distance was $19.2 \mathrm{~mm}$ in the CMN group and $17.9 \mathrm{~mm}$ in the SHS group. A statistically significant difference was found between tip-apex distance 
measurements according to the implant type $(p<0.05)$; the tip-apex distances in patients who underwent $\mathrm{CMN}$ were longer than in the SHS group. There was a loss of neck length (fracture settling) in both groups of average 10.6 $\mathrm{mm}$ in the SHS group and $6.7 \mathrm{~mm}$ in the CMN group. A statistically significant difference was found between the fracture settling measurements according to the implant type $(p<0.01)$; the measurements of SHS were higher than those of $\mathrm{CMN}$. Fracture settling was determined in the first 6 weeks postoperatively but not thereafter.

The average Singh grade was 4 in the SHS group and 3.9 in the CMN group. Moderate or poor quality of reduction was determined in $22.2 \%$ of patients in the SHS group and in $13.9 \%$ of patients in the CMN group.

The pre-fracture Modified Barthel index was 94.5 in the SHS group and 93.0 in the CMN group, with no significant difference determined between the groups. The index was applied at every visit. Continuous improvement in the Barthel index was seen over the 12-month period, but the index did not return to pre-fracture values in either group $(p<0.05)$. No difference was determined in Barthel index values between the groups at any of the measured time points. The average mobility score decreased from 8.4 points to 6.0 in the SHS group and from 8.5 points to 7.1 in the CMN group at the $6^{\text {th }}$ week follow-up visit. These values were considered statistically significant $(p<0.05)$. The average Harris Hip score of all the patients was $70.59 \pm 9.50$. The preoperative Harris score was regained in the post-operative $3^{\text {rd }}$ month by $40 \%$ of patients and by $80 \%$ at the final follow-up (12 months). The detailed distributions of functional and radiological outcomes are given in Table 2.

In one patient of the SHS group, implant cut-out developed despite adequate initial reduction and implant position. No implant cut-out was seen in the CMN group. No surgery-related infections or wound complications developed in any patient in this study.

\section{Discussion}

Proximal femoral fractures are one of the most commonly treated conditions by orthopaedic trauma surgeons. However, one of the least encountered fractures

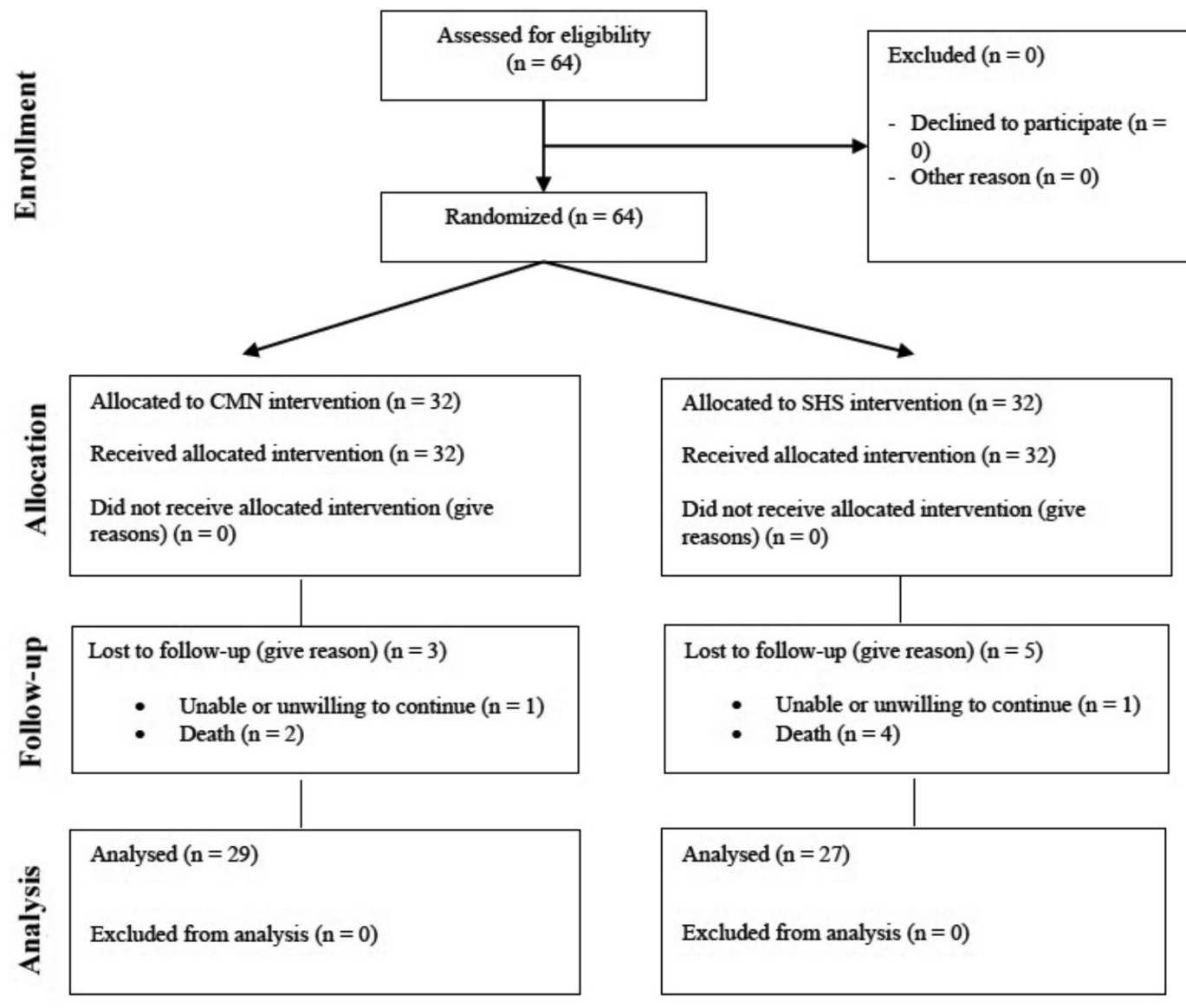

Figure 3. Consolidated Standarts of Reporting Trials (CONSORT) 2010 flow diagram depicting fracture allotment in both groups CMN: Cephalomedullary nail, SHS: Sliding hip screw, n: Number of the patients 
is basicervical fracture. These relatively rare fractures account for $1.8 \%-3.5 \%$ of all proximal femur fractures $(2,4,23)$. In a 2-year period, 2207 patients were treated for proximal femur fractures in our institution and only $2.9 \%(n=64)$ had real basicervical fractures. This finding is comparable with the data of previous studies.

Many implants have been used to reconstruct the hip anatomy after basicervical fractures $(10,24-26)$. Fixation of basicervical fractures is difficult, because of the unique nature of the anatomy and the best fixation implants are probably fixed-angle implants, such as SHS and CMN $(24,27)$.

For many types of hip fractures, SHS is the preferred implant. Some authors have stated that a basicervical fracture should be treated as an extra-capsular fracture and they have recommended osteosynthesis with SHS $(26,28)$.
However, others have suggested that SHS alone would not provide sufficient rotational stability and it would be necessary to apply a derotation screw $(26,29)$. Saarenpää et al. (2) retrospectively reviewed 1624 hip fractures in an 8-year period and found 30 (1.8\%) basicervical fractures, of which 16 were treated as intracapsular hip fractures and 14 as extracapsular. The authors reported that when treated with SHS (like an extracapsular hip fracture), better results were obtained than with hemiarthroplasty (like an intracapsular hip fracture). However, some authors have stated that basicervical fractures were unstable extracapsular fractures and could show good outcomes when treated with $\mathrm{CMN}(30,31)$.

Statistically, modified Barthel index, Mobility score and Harris Hip score would seem to be age- and time-dependent, independent of other parameters and implant type.

\begin{tabular}{|c|c|c|c|c|}
\hline & & $\begin{array}{l}\text { SHS } \\
\mathrm{n}=27(48.2 \%)\end{array}$ & $\begin{array}{l}\text { CMN } \\
\mathrm{n}=29(51.8 \%)\end{array}$ & $p$ \\
\hline \multirow[t]{2}{*}{ Age (year) } & Min-Max (median) & $66-96(81)$ & $66-92(81)$ & $\mathrm{a} 0.545$ \\
\hline & $A v . \pm S D$ & $80.11 \pm 8.23$ & $81.34 \pm 6.92$ & - \\
\hline \multirow[t]{2}{*}{ Gender } & Female & $16(59.3)$ & $14(48.3)$ & ${ }^{\circ} 0.410$ \\
\hline & Male & $11(40.7)$ & $15(51.7)$ & - \\
\hline \multirow[t]{3}{*}{ Singh index } & Min-Max (median) & $2-6(4)$ & $1-6(4)$ & a0.594 \\
\hline & $A v . \pm S D$ & $4.07 \pm 1.07$ & $3.90 \pm 1.37$ & - \\
\hline & $A v \pm S D$ & $93.15 \pm 5.57$ & $92.41 \pm 6.63$ & - \\
\hline \multirow[t]{2}{*}{ Side } & Right & $16(59.3)$ & $15(51.7)$ & ${ }^{c} 0.571$ \\
\hline & Left & $11(40.7)$ & $14(48.3)$ & - \\
\hline \multirow{2}{*}{$\begin{array}{l}\text { Time interval between trauma to } \\
\text { operation (day) }\end{array}$} & Min-max (median) & $2-12(5)$ & 2-17 (5) & b0.823 \\
\hline & Av. $\pm S D$ & $5.37 \pm 2.80$ & $5.76 \pm 3.47$ & - \\
\hline
\end{tabular}

Table 2. Distributions of functional and radiological outcomes

\begin{tabular}{|c|c|c|c|c|}
\hline & & $\begin{array}{l}\text { SHS } \\
n=27(48.2 \%)\end{array}$ & $\begin{array}{l}\text { CMN } \\
\mathrm{n}=29(51.8 \%)\end{array}$ & p \\
\hline \multirow[t]{2}{*}{ Harris Hip score } & Min-max (median) & $61-93(68)$ & $60-96(68)$ & b0.621 \\
\hline & $A v . \pm S D$ & $70.81 \pm 8.99$ & $70.38 \pm 10.10$ & - \\
\hline \multirow[t]{2}{*}{ Barthel index } & Min-max (median) & $80-100(95)$ & $80-100(95)$ & $\mathrm{a} 0.657$ \\
\hline & $A v . \pm S D$ & $93.15 \pm 5.57$ & $92.41 \pm 6.63$ & - \\
\hline \multirow[t]{2}{*}{ Tip-apex distance (mm) } & Min-max (median) & $14-22(17)$ & $16-23(19)$ & a0.010* \\
\hline & Av. $\pm S D$ & $17.85 \pm 1.99$ & $19.21 \pm 1.78$ & - \\
\hline \multirow[t]{2}{*}{ Fracture settling (mm) } & Min-max (median) & 7-14 (10) & $1-5(3)$ & b 0.001 ** \\
\hline & $A v . \pm S D$ & $10.63 \pm 2.20$ & $3.07 \pm 1.19$ & - \\
\hline \multirow[t]{3}{*}{ Reduction quality } & Poor & $2(7.4)$ & $1(3.5)$ & do.664 \\
\hline & Acceptable & $4(14.8)$ & $3(10.3)$ & - \\
\hline & Good & $21(77.8)$ & $25(86.2)$ & - \\
\hline
\end{tabular}


The results of this study showed that treatment with CMN (average fracture settling $6.7 \mathrm{~mm}$ ) caused significantly less femoral neck shortening, with almost $5 \mathrm{~mm}$ more shortening in the SHS group (average fracture settling 10.6 $\mathrm{mm}$ ). However, this finding was not significantly correlated with any functional impairment in this study. Reindl et al. (20) reported similar results for unstable intertrochanteric fractures in a comparison between CMN and SHS.

A serious complication of these fractures is implant cut-out, for reasons including low bone density, unstable fracture, and insufficient reduction (32). Although the average Singh index value was $3.98 \pm 1.23$ in the current study patients, no serious collapse or complications were detected. Furthermore, no implant cut-out or protrusion occurred in any patient. There was no significant difference between the SHS and CMN groups in respect of the Singh index and fracture settling.

Early post-operative mobilization of patients after hip fractures is fundamental to enable a return to normal life and to prevent medical complications (33). All the patients in the current study were mobilized on postoperative day 1 and weight-bearing was allowed as tolerated. Although radiological fracture healing was seen at mean 10 weeks in all patients, clinical healing was achieved in mean 6 weeks. There were no cases of implant cut-out, peri-implant femur fracture, and no wound site infections, despite weightbearing permitted in the early post-operative period.

\section{Study Limitation}

The main limitation of this study was the loss of study participants, primarily because of mortality of almost $10 \%$ $(n=6 / 64)$ within the first year after hip fracture, and a further two patients did not attend the last 2 follow-up visits. Another important limitation was the limited number of patients that preclude any definite conclusions being made.

\section{Conclusion}

The results of the current study regarding basicervical fracture treatment do not clearly favor one implant over another. CMN resulted in significantly less shortening across the fracture site compared to SHS, but this did not show any significant difference in the extremity or general function as measured with the Harris Hip score, Barthel index and mobility score. It can be considered that basicervical fractures should be classified as unstable intertrochanteric fractures, not as femoral neck fractures, as in the AO classification, because of the implants used and the nature of the fracture in response to treatment.

\section{Authorship Contributions}

Concept: E.E. Design: E.E. Data Collection or Processing: H.B.Ç. Analysis or Interpretation: G.B. Literature Search: H.B.Ç. Writing: H.B.Ç., E.E.
Conflict of Interest: No conflict of interest was declared by the authors.

Financial Disclosure: The authors declared that this study received no financial support.

\section{References}

1. Masionis $P$, Uvarovas $V$, Mazarevičius $G$, et al. The reliability of a Garden, $\mathrm{AO}$ and simple II stage classifications for intracapsular hip fractures. Orthopaedics \& Traumatology: Surgery \& Research 2019;105:29-33.

2. Saarenpää I, Partanen J, Jalovaara P. Basicervical fracture-a rare type of hip fracture. Archives of orthopaedic and trauma surgery 2002;122:69-72.

3. Okano I, Sawada T, Kushima N, et al. Treatment with helical blade cephalomedullary nail for two-part basicervical proximal femoral fracture in elderly patients: a retrospective observational study. Geriatric orthopaedic surgery \& rehabilitation 2017;8:244-51.

4. Lee $Y-K$, Yoon B-H, Hwang JS, et al. Risk factors of fixation failure in basicervical femoral neck fracture: Which device is optimal for fixation? Injury 2018;49:691-6.

5. Massoud EIE. Fixation of basicervical and related fractures. International orthopaedics 2010;34:577-82.

6. Kim W-Y, Han C-H, Park J-I, Kim J-Y. Failure of intertrochanteric fracture fixation with a dynamic hip screw in relation to preoperative fracture stability and osteoporosis. International orthopaedics 2001;25:360-2.

7. Aktselis I, Kokoroghiannis C, Fragkomichalos E, et al. Prospective randomised controlled trial of an intramedullary nail versus a sliding hip screw for intertrochanteric fractures of the femur. International orthopaedics 2014;38:155-61.

8. Haynes R, Pöll R, Miles A, Weston R. An experimental study of the failure modes of the gamma locking nail and $A O$ dynamic hip screw under static loading: a cadaveric study. Medical engineering \& physics 1997;19:446-53.

9. Kwak DK, Kim WH, Lee SJ, et al. Biomechanical Comparison of Three Different Intramedullary Nails for Fixation of Unstable Basicervical Intertrochanteric Fractures of the Proximal Femur: Experimental Studies. BioMed research international eCollection 2018. doi: https://doi. org/10.1155/2018/7618079

10. Watson ST, Schaller TM, Tanner SL, Adams JD, Jeray KJ. Outcomes of low-energy basicervical proximal femoral fractures treated with cephalomedullary fixation. JBJS 2016;98:1097-102.

11. Tan BY, Lau ACK, Kwek EBK. Morphology and fixation pitfalls of a highly unstable intertrochanteric fracture variant. Journal of Orthopaedic Surgery. 2015;23:142-5.

12. Su BW, Heyworth BE, Protopsaltis TS, et al. Basicervical versus intertrochanteric fractures: an analysis of radiographic and functional outcomes. Orthopedics 2006;29:919-25. 
13. Johnson J, Deren M, Chambers A, Cassidy D, Koruprolu $\mathrm{S}$, Born C. Biomechanical Analysis of Fixation Devices for Basicervical Femoral Neck Fractures. JAAOS-Journal of the American Academy of Orthopaedic Surgeons 2019;27:e41-8.

14. Parker MJ, Palmer CR. A new mobility score for predicting mortality after hip fracture. The Journal of bone and joint surgery British volume 1993;75:797-8.

15. Harris WH. Traumatic arthritis of the hip after dislocation and acetabular fractures: treatment by mold arthroplasty. An end-result study using a new method of result evaluation. The Journal of bone and joint surgery American volume 1969;51:737-55.

16. Mahoney FI, Barthel DW. Functional evaluation: the Barthel Index: a simple index of independence useful in scoring improvement in the rehabilitation of the chronically ill. Maryland state medical journal. 1965;14:61-5.

17. Koot V, Kesselaer S, Clevers GJ, De Hooge P, Weits T, van der Werken C. Evaluation of the Singh index for measuring osteoporosis. The Journal of bone and joint surgery British volume. 1996;78:831-4.

18. Singh $M$, Nagrath AR, Maini P. Changes in trabecular pattern of the upper end of the femur as an index of osteoporosis. JBJS 1970;52:457-67.

19. Baumgaertner MR, Curtin SL, Lindskog DM, Keggi JM. The value of the tip-apex distance in predicting failure of fixation of peritrochanteric fractures of the hip. JBJS 1995;77:105864.

20. Reindl R, Harvey EJ, Berry GK, Rahme E. Intramedullary Versus Extramedullary Fixation for Unstable Intertrochanteric Fractures: A Prospective Randomized Controlled Trial. The Journal of bone and joint surgery American volume 2015;97:1905-12.

21. Vidyadhara S, Rao SK. One and two femoral neck screws with intramedullary nails for unstable trochanteric fractures of femur in the elderly-randomised clinical trial. Injury 2007;38:806-14.

22. Schulz KF, Altman DG, Moher D. CONSORT 2010 Statement: Updated guidelines for reporting parallel group randomised trials. J Clin Epidemiol 2010;63:834-40.

23. Chen CY, Chiu FY, Chen CM, Huang CK, Chen WM, Chen $\mathrm{TH}$. Surgical treatment of basicervical fractures of femur-a prospective evaluation of 269 patients. Journal of Trauma and Acute Care Surgery 2008;64:427-9.

24. Blair B, Koval KJ, Kummer F, Zuckerman JD. Basicervical fractures of the proximal femur. A biomechanical study of 3 internal fixation techniques. Clinical orthopaedics and related research 1994:256-63.

25. Kim JT, Ha YC, Park CH, Yoo Jl, Kim TY. Single screw type of lag screw results higher reoperation rate in the osteosynthesis of basicervical hip fracture. Journal of orthopaedic science : official journal of the Japanese Orthopaedic Association. 2020;25:152-5.

26. Massoud El. Fixation of basicervical and related fractures. Int Orthop 2010;34:577-82.

27. Deneka DA, Simonian PT, Stankewich C, Eckert D, Chapman $J R$, Tencer AF. Biomechanical comparison of internal fixation techniques for the treatment of unstable basicervical femoral neck fractures. Journal of orthopaedic trauma 1997;11:33743.

28. Mallick A, Parker MJ. Basal fractures of the femoral neck: intra-or extra-capsular. Injury 2004;35:989-93.

29. Kuokkanen $\mathrm{H}$. Treatment options for basicervical fractures of the femoral neck. A clinical follow-up. Acta Orthop Belg 1991;57:162-8.

30. Hu SJ, Yu GR, Zhang SM. Surgical treatment of basicervical intertrochanteric fractures of the proximal femur with cephalomeduallary hip nails. Orthopaedic surgery 2013;5:1249.

31. Tasyikan L, Ugutmen E, Sanel S, Soylemez MS, Ozkan K, Solakoglu C. Short-term results of surgical treatment with cephalomedullary nails for basicervical proximal femoral fractures. Acta Orthop Belg 2015;81:427-34.

32. Barrios C, Brostrom LA, Stark A, Walheim G. Healing complications after internal fixation of trochanteric hip fractures: the prognostic value of osteoporosis. J Orthop Trauma 1993;7:438-42.

33. Aharonoff GB, Koval KJ, Skovron ML, Zuckerman JD. Hip fractures in the elderly: predictors of one year mortality. J Orthop Trauma 1997;11:162-5. 